\title{
PERAN VITAMIN D DALAM REGULASI SISTEM IMUNITAS MELALUI SEL DENDRITIK
}

\author{
Wira Daramatasia \\ Program Studi Ilmu Keperawatan \\ STIKES Widyagama Husada
}

\begin{abstract}
Dendritic cells are antigen presenting cells (APC) that initiate professional cellular immune response and humoral immunity. Differentiation and maturation of dendritic cells affects their capacity. Known differentiation and maturation of dendritic cells is affected vitamin $D$. The purpose of this paper was to determine the mechanism of vitamin $D$ in regulating the immune response by dendritic cells. Vitamin $D$ has the effect of inhibiting monocyte differentiation into dendritic cells and inhibits dendritic cell maturation process, and maintain in a state of immature dendritic cells. Vitamin D inhibits T cell-dependent activation of dendritic cells, reduce the secretion of Th1 and Th2 cytokines and induce regulatory $T$ cell development.
\end{abstract}

Key words: Vitamin D, Dendritic Cells 


\begin{abstract}
ABSTRAK
Sel dendritik merupakan antigen presenting cells (APC) profesional yang mengawali respon imunitas seluler dan imunitas humoral. Differensiasi dan maturasi sel dendritik mempengaruhi kapasitasnya. Diketahui differensiasi dan maturasi sel dendritik dipengaruhi vitamin D. Tujuan dari makalah ini adalah mengetahui mekanisme vitamin D dalam regulasi sistem imun melalui sel dendritik. Vitamin D memiliki efek menghambat differensiasi sel monosit menjadi sel dendritik dan menghambat proses maturasi sel dendritik, kemudian mempertahankan sel dendritik dalam kondisi imatur. Vitamin D menghambat aktivasi sel Tyang tergantung sel dendritik, menurunkan sekresi sitokin Th1 dan Th2 serta menginduksi perkembangan sel $T$ regulator.
\end{abstract}

\title{
Kata Kunci : Vitamin D, Sel Dendritik
}

\section{PENDAHULUAN}

\section{Latar Belakang}

Dalam sistem imun, sel dendritik mempunyai peran yang sangat penting yakni sebagai Antigen Presenting Cells (APC) profesional yang mengawali respon imunitas seluler dan imunitas humoral, selain itu berperan dalam mekanisme toleransi perifer (Rossi et al., 2005). Untuk menginduksi autoimunitas, auto-antigen perlu dipresentasikan ke sel T auto-reaktif melalui APC. Sel dendritik sebagai APC yang profesional merangsang sel T naive. Umumnya, sel dendritik yang bersirkulasi di sekitar tubuh kita berperan sebagai "penjaga", dimana dapat memberikan sinyal "aman" atau "berbahaya" dan memberikan reaksi dengan menginduksi sistem kekebalan atau toleransi (Ou Jin et al., 2008).

Akhir-akhir ini telah dilaporkan adanya hubungan antara timbulnya penyakit autoimun dengan defisiensi vitamin D (Toubi et al., 2010). Berbagai laporan terkini menyatakan terdapatnya persentase tinggi pada penderita autoimun khususnya Lupus Eritematosus Sistemik (LES) yang mengalami defisiensi vitamin D (Constenbader et al., 2008). Dilaporkan bahwa vitamin D memiliki efek meregulasi sistem imun (Cutolo, 2009).

Berdasarkan latar belakang tersebut, maka dikemukakan rumusan masalah bagaimanakah mekanisme vitamin D dalam regulasi sistem imun pada sel dendritik, sedangkan tujuannya untuk mengetahui mekanisme vitamin $\mathrm{D}$ dalam regulasi sistem imun pada sel dendritik.

\section{TINJAUAN PUSTAKA}

\section{Metabolisme Vitamin D}

Vitamin D merupakan vitamin larut lemak yang bersifat secosteroid (mirip steroid) dengan metabolit aktif yaitu 1,25-dihidroksi vitamin $\mathrm{D}\left[1,25(\mathrm{OH})_{2} \mathrm{D}\right]$.
Vitamin D bukanlah vitamin murni, karena pemenuhan kebutuhan vitamin D tidak hanya didapat melalui konsumsi makanan yang mengandung vitamin $\mathrm{D}$, melainkan dapat juga disintesis oleh tubuh melalui pajanan sinar matahari (Bikle, 2009).

Metabolit aktif vitamin D yaitu 1,25-dihidroksi vitamin $\mathrm{D}\left[1,25(\mathrm{OH})_{2} \mathrm{D}\right]$ memiliki aktifitas hormon, sehingga vitamin $\mathrm{D}$ disebut juga sebagai suatu prohormon. Vitamin D dapat diperoleh dari makanan, suplemen, dan melalui proses sintesis endogen di kulit dari 7-dehidrokolesterol setelah kulit terpapar sinar matahari yang berupa ultraviolet B (UVB) (Bikle, 2009).

7-dehidrokolesterol terdistribusi di seluruh lapisan epidermis dan dermis, dengan konsentrasi tertinggi terdapat pada lapisan stratum spinosum dan stratum basal. Paparan sinar matahari terhadap kulit menyebabkan terjadinya konversi fotolitik dari 7-dehidrokolesterol menjadi previtamin $\mathrm{D}_{3}$. Previtamin $\mathrm{D}_{3}$ ditransformasi menjadi vitamin $\mathrm{D}_{3}$ melalui proses isomerisasi yang diinduksi secara termal. Proses sintesis endogen di kulit ini menghasilkan vitamin $\mathrm{D}_{3}$ (kolekalsiferol), kemudian akan ditranspor ke hati oleh vitamin D binding protein (DBP). Pada makanan maupun suplemen, vitamin $\mathrm{D}$ dapat berada dalam bentuk kolekalsiferol (vitamin $\mathrm{D}_{3}$ ) atau ergokalsiferol (vitamin $\mathrm{D}_{2}$ ). Setelah berada di hati, vitamin D diubah oleh enzim 25hidroksilase (25-Ohase) menjadi 25-hidroksi vitamin D [25(OH)D]. 25-hidroksivitamin D [25(OH)D] di sirkulasi inilah yang digunakan untuk menentukan status vitamin D. Bentuk vitamin $\mathrm{D}$ ini $[25(\mathrm{OH}) \mathrm{D}]$ secara biologis inaktif dan harus diubah diginjal menjadi bentuk aktif berupa 1,25-dihidroksivitamin D $\left[1,25(\mathrm{OH})_{2} \mathrm{D}\right]$ oleh 25-hidroksi vitamin D-1á-hidroksilase (1OHase), selanjutnya melalui proses hidroksilasi atom C-1 oleh CYP27B1 dalam ginjal untuk memproduksi $1,25(\mathrm{OH})_{2} \mathrm{D}_{3}$ atau $1,25(\mathrm{OH})_{2} \mathrm{D}_{2^{\prime}}$ yang dikenal dengan nama kalsitriol (Dusso et al., 2005) (Gambar 1) 


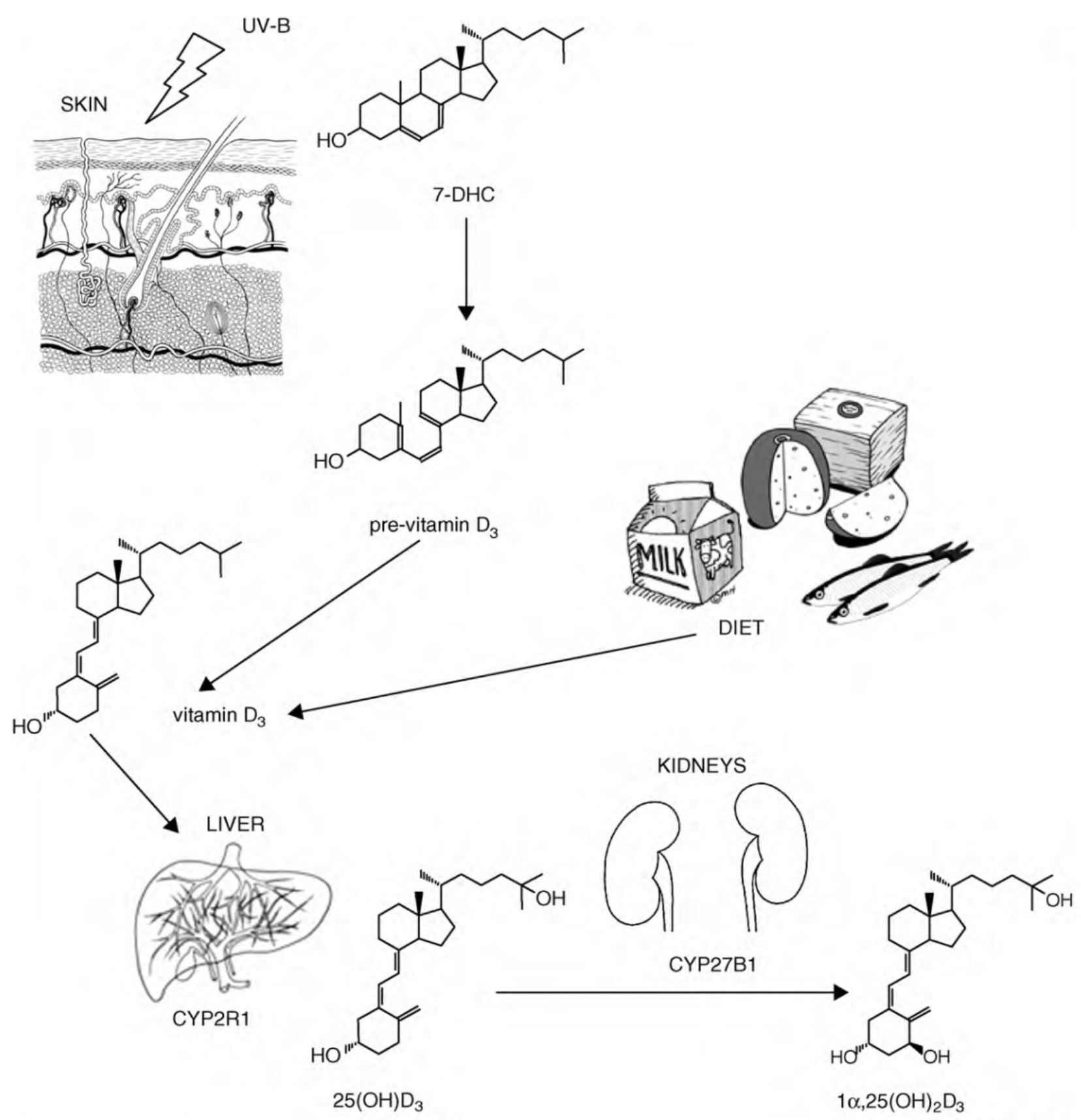

Gambar 1 Proses Metabolisme Vitamin D

Sintesis vitamin D3 terjadi pada kulit dimana 7-dehydrocholesterol (7-DHC) dikonversi menjadi previtamin D3 setelah terpapar sinar UV. Vitamin D3,diperoleh dari pre-vitamin D3 di kulit atau usus yang merupakan hasil penyerapan komponen makanan, kemudian ditranspor ke hati oleh vitamin D binding protein (DBP). Setelah berada di hati, vitamin D diubah oleh enzim 25-hidroksilase (25-Ohase /CY2R1) menjadi 25-hidroksi vitamin D [25(OH)D]. 25-hidroksi vitamin D [25(OH)D] kemudian dihidroksilasi 1-a-hidroksilase (CYP27B1) didalam ginjal, menghasilkan hormon aktif 1,25 (OH) 2D3 (Baeke et al., 2010).

Tahap bioaktifasi vitamin $\mathrm{D}$, yaitu dari $25(\mathrm{OH}) \mathrm{D}$ menjadi $1,25(\mathrm{OH})_{2} \mathrm{D}$ terjadi pada kondisi fisiologis, terutama terjadi di ginjal. Selain di ginjal, produksi $1,25(\mathrm{OH})_{2} \mathrm{D}$ juga terjadi di berbagai sel atau jaringan. Produksi $1,25(\mathrm{OH})_{2} \mathrm{D}$ ekstrarenal ini memiliki fungsi autokrin/parakrin dengan fungsi yang spesifik. Saat ini, 1a-OHase dilaporkan terdapat di berbagai sel dan jaringan termasuk prostat, payudara, kolon, paru, sel beta pankreas, sel monosit, dan sel paratiroid (Dusso et al., 2005).

25-hidroksivitamin D [25(OH)D] merupakan bentuk sirkulasi utama vitamin $\mathrm{D}$, waktu paruh 25(OH)D serum sekitar 10 hari sampai 3 minggu. Konsentrasi $25(\mathrm{OH}) \mathrm{D}$ serum adalah indikator status vitamin $\mathrm{D}$, karena memberikan gambaran 
yang baik dari efek kumulatif paparan sinar matahari dan asupan makanan, oleh karena itu konsentrasi 25(OH)D digunakan sebagai kriteria diagnostik defisiensi vitamin $\mathrm{D}$ (Vanamerongen et al., 2004).

Sebagian ahli berpendapat bahwa nilai konsentrasi serum $25(\mathrm{OH}) \mathrm{D}$ pada populasi sehat merupakan indikator terbaik untuk menilai status vitamin $\mathrm{D}$ pada pasien dengan penyakitpenyakit yang berhubungan dengan vitamin $\mathrm{D}$ (Holick, 2006). Hal ini didukung karena :

1. Tidak tersedianya uji klinik khusus vitamin D.

2. Metabolisme vitamin $\mathrm{D}_{3}$ menjadi $25(\mathrm{OH}) \mathrm{D}_{3}$ oleh enzim 25-hidroksilase dihati tidak diregulasi, sehingga konsentrasi serum $25(\mathrm{OH}) \mathrm{D}_{3}$ merupakan nilai akurat vitamin Dbaik yang berasal dari makanan ataupun dari hasil sintesis di kulit, sedangkan pengukuran $1,25(\mathrm{OH})_{2} \mathrm{D}$ tidak memberikan gambaran tentang status vitamin $\mathrm{D}$ pasien. $1,25(\mathrm{OH})_{2} \mathrm{D}$ sering normal atau kadang-kadang meningkat pada pasien defisiensi vitamin $\mathrm{D}$, hal ini disebabkan karena kadar 1,25(OH) 2,1000 kali lebih rendah dibandingkan kadar $25(\mathrm{OH}) \mathrm{D}$ dan saat seseorang mengalami defisiensi vitamin $\mathrm{D}$ dan konsentrasi $25(\mathrm{OH}) \mathrm{D}$ menurun, kadar $1,25(\mathrm{OH})_{2} \mathrm{D}$ dipertahankan dalam batas normal melalui mekanisme kompensasi peningkatan sekresi hormon paratiroid, yang menstimulasi ginjal untuk memproduksi lebih banyak $1,25(\mathrm{OH})_{2} \mathrm{D}$.

3. Waktu paruh 25(OH)D sekitar 2 minggu sedangkan $1,25(\mathrm{OH})_{2} \mathrm{D}$ kurang dari 4 jam.

4. Berbagai uji klinik tersedia untuk mengukur 25(OH)D

\section{Sel Dendritik}

Sel dendritik berasal dari dalam sumsum tulang atau dari prekursor monosit di dalam darah. Keberadaan sel dendritik hanya 1\%-3\% dari peripheral blood mononuclear cells (PBMC), tetapi di distribusikan di dalam berbagai jenis jaringan (Ferreira et al., 2010). Ada 2 subset sel dendritik di perifer yang diidentifikasi berdasarkan ekspresi CD11c, yaitu CD11 $\mathrm{c}^{+}$myeloid dendritic cells (M-DC) dan CD11c plasmacytoid dendritic cells (P-DC). Distribusi kedua subset sel dendritik tersebut berbeda, CD11c plasmacytoid dendritic cells (P-DC) terutama pada jaringan limfoid, sedangkan

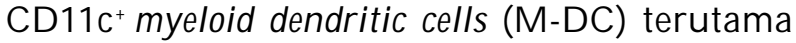
berlokasi di kulit dan jaringan mukosa (Gambar 2). Subset $\mathrm{CD}_{11 \mathrm{c}^{+}}$mengikuti jalur diferensiasi myeloid dimana sel monosit sebagai prekursor (Rossi and James., 2005).
Secara fenotipik berdasarkan ekspresi penanda permukaan/Cluster of Differentiation (CD) sel dendritik diidentifikasikan sebagai sel dendritik imatur (immature dendritic cells/iDC) dan sel dendritik matur (mature dendritic cells/mDC). Pada permukaan sel dendritik matur sebagian besar mengekspresikan CD83 yang merupakan salah satu molekul transmembran yang paling karakteristik pada permukaan sel dendritik, termaksuk sel dendritik di timus, sel langerhans di kulit, zona T pada organ limfoid dan monocyte-derived dendritic cells (moDCs) (Kuwano et al., 2007).

Kapasitas sel dendritik tergantung pada maturasi dan aktivasinya. Sel dendritik imatur (iDC) memiliki kapasitas tinggi untuk mengidentifikasi patogen karena permukaan sel yang mampu mengenali pathogen-associated molecular patterns (PAMPs) melalui pattern recognition receptors (PRRs). pattern recognition receptors (PRRs) yang terbaik adalah tool-like receptors (TLRs), TLRs terdapat di berbagai sel, termasuk sel dendritik (Maddur et al., 2010). Kemampuan sel dendritik imatur (iDC) dalam mengekspresikan molekul kostimulator sangat kurang bahkan tidak ada, hal ini menyebabkan sel dendritik imatur (iDC) dalam menstimulasi sel $\mathrm{T}$ berkurang (Vlad et al., 2005).

Setelah priming dengan stimulasi inflamasi atau infeksi melalui pengenalan PRRs, sel dendritik imatur (iDC) menjalani proses maturasi melalui beberapa tahapan: 1) perubahan dalam bentuk morfologi, hilangnya struktur adesi, dan perubahan motilitas; 2) Meningkatkan molekul kostimulator; 3) Migrasi ke organ limfoid sekunder yaitu limpa dan kelenjar getah bening; 4) Mobilisasi molekul MHC II dari dalam vesikel di sitoplasma ke permukaan sel; 5) Sekresi dari kemokin dan sitokin (Ferreira et al., 2010). Proses maturasi dan aktivasi sel dendritik tergantung dari rangsangan di lingkungannya, molekul tersebut meliputi pathogen-derived molecules (seperti LPS), komponen sel apoptosis, heparin sulfat, imun komplek dan sitokin inflamator (Nie et al., 2010). Setelah sel dendritik matur (mDC) kapasitas menangkap antigen berkurang, namun sangat efisien dalam menstimulasi sel limfosit $\mathrm{T}$ (Ferreira et al., 2010). Sel dendritik yang teraktivasi mensekresi sitokin yang berpengaruh terhadap imunitas innate maupun adaptive. 


\section{PRECURSORS ITEADY STATE INFLAMMATION}

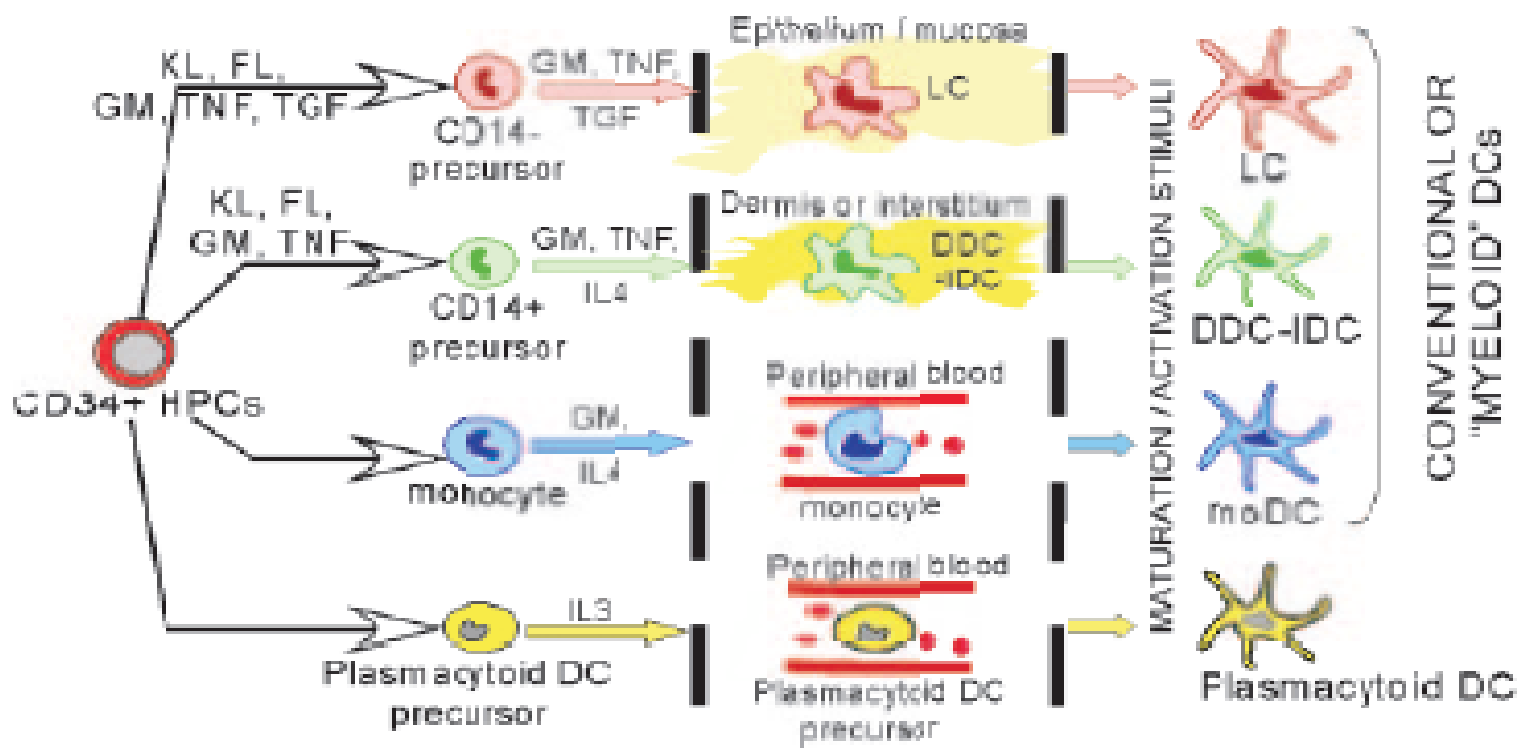

Gambar 2 Perkembangan Subset Sel Dendritik.

Prekursor sel dendritik yang berasal dari sumsum tulang (bagian kiri) dapat menimbulkan empat jenis sel dendritik (kondisi ex vivo). Populasi dari sel dendritik imatur/sel dendritik yang belum teraktivasi ditemukan di perifer/sirkulasi. Pada organ limfoid sekunder sel dendritik imatur mempertahankan toleransi perifer dan anergi. Stimulus maturasi sel dendritik membutuhkan kondisi inflamasi (bagian kanan), secara fisiologis berasal dari patogen mikroba atau dari ekspresi CD40L yang berasal dari sel $\mathrm{T} \mathrm{CD4}{ }^{+}$teraktivasi (Rossi and James., 2005). Keterangan $\mathrm{LC}=$ langerhans cells, $\mathrm{DDC}=$ derived dermal dendritic cells, IDC= Interstitial dendritic cells, $\mathrm{moDC}=$ monocyte derived dendritic cells.

\section{PEMBAHASAN}

\section{Peran Vitamin D dalam Regulasi Sistem Imun Melalui Sel Dendritik}

Berbagai penelitian memfokuskan pada interaksi metabolit vitamin $\mathrm{D}$ tersebut dengan reseptor vitamin D (VDR), yang merupakan bagian dari kelompok reseptor steroid. Reseptor vitamin D (VDR) diekspresikan oleh limfosit T, limfosit B dan sel monosit yang berdiferensiasi menjadi sel dendritik (Monocyte-derived dendritic cells / moDCs) (Zvi et al., 2010). Kemampuan 1,25(OH) ${ }_{2} \mathrm{D}$ dalam menghambat pertumbuhan dan merangsang diferensiasi berbagai tipe sel membuka kemungkinan kemampuan lain vitamin D dalam mencegah kanker, memodulasi sistem imun dan mengatur beberapa sistem endokrin (Chen et al., 2007). Disebutkan bahwa efek vitamin D lebih kuat dalam meningkatkan imunitas selular daripada imunitas humoral telah diajukan sebagai salah satu mekanisme kunci bagaimana vitamin D dapat memberikan efek yang menguntungkan dalam penyakit autoimun (Gambar 3).
Regulasi sistem imun melalui vitamin D dengan metabolit aktifnya $1,25(\mathrm{OH})_{2} \mathrm{D}$ dalam memodulasi respon imun didasarkan atas

1. Adanya VDR pada makrofag, sel monosit, sel limfosit T dan B yang teraktivasi.

2. Kemampuan makrofag, sel dendritik, sel T dan B teraktivasi untuk mengekspresikan CYP27B1 (enzim yang memproduksi $1.25(\mathrm{OH})_{2} \mathrm{D}$ ).

3. Kemampuan $1,25(\mathrm{OH})_{2} \mathrm{D}_{3}$ untuk mengatur proliferasi dan fungsi makrofag, sel dendritik, serta sel T dan B (Bikle., 2009).

Data terbaru menyatakan bahwa target untuk respon imun adaptif pada vitamin $\mathrm{D}$ ada-lah sel dendritik (Adam dan Hewison., 2008). APC, terutama sel dendritik adalah target utama dari ligan VDR, baik in vitro dan in vivo (Adorini et al., 2004). Vitamin D dilaporkan memiliki efek menghambat diferensiasi sel monosit menjadi sel dendritik (Cutolo, 2009), kemudian mempertahankan sel dendritik dalam kondisi imatur (Dusso et al., 2005). 1,25-dihydroxyvitamin D $[1,25(\mathrm{OH}), \mathrm{D}]$ menginduksi penurunan ekspresi dari molekul kostimulator CD40, CD80, CD86 dan IL-12, secara bersama meningkatkan produksi IL-10, mempromosikan sel dendritik 


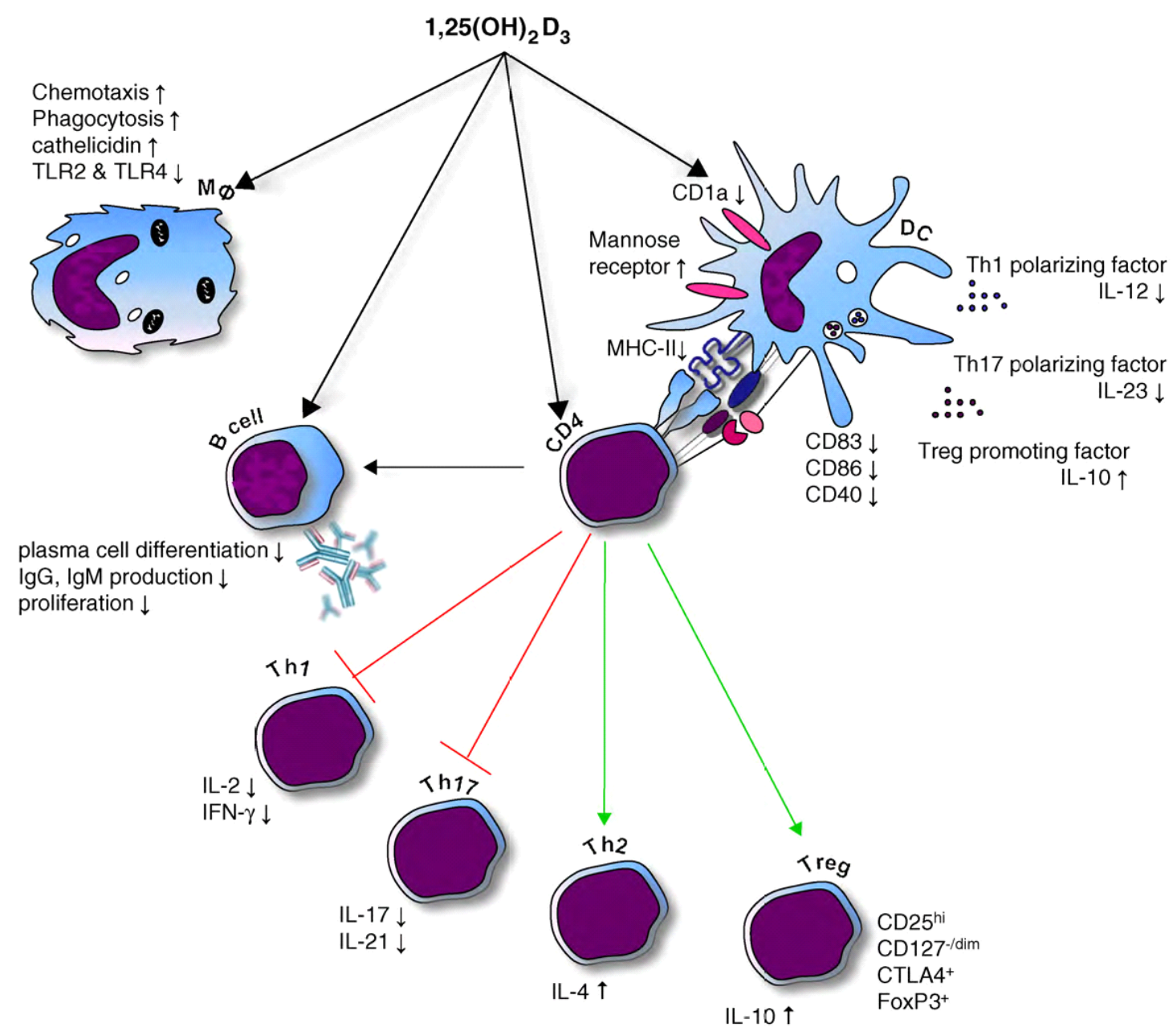

Gambar 3: Regulasi Respon Imun oleh Vitamin D.

$1,25(\mathrm{OH})_{2} \mathrm{D}_{3}$ menstimulasi respon imun bawaan (innate immunity) dengan meningkatkan chemotaxis dan respon phagocytotic dari makrofag serta produksi protein antimikroba seperti cathelicidin. Sebaliknya, Vitamin D mensupresi imunitas adaptif dengan menghambat maturasi sel-sel dendritik, menurunkan kapasitas mereka dalam mempresen-tasikan antigen kepada sel CD4. Vitamin D kemudian menginhibisi proliferasi dan diferensiasi sel CD4 untuk menjadi sel Th1 dan Th17 dan meningkatkan produksi sel Th2 dan Treg. Pada akhirnya1,25 (OH) 2D3 menginhibisi diferensiasi sel plasma, menurunkan produksi IgG dan IgM serta menurunkan proliferasi sel B (Baeke et al., 2010).

untuk apoptosis dan menghambat aktivasi sel $\mathrm{T}$ (Cutolo, 2009). Selanjutnya 1,25(OH)2D3 menghambat ekspresi dari sitokin inflamasi monosit, termasuk IL-1, IL-6, TNF-á, IL-8, dan IL-12 (Baeke et al., 2010) (Gambar 4). 1,25(OH)2D3 juga memodulasi sel dendritik mengekspresikan sitokin dan kemokin, dengan menghambat produksi IL-12 dan IL-23 (dikenal sebagai sitokin yang berperan dalam differensiasi Th1 dan diferensiasi Th17), dan meningkatkan pelepasan IL-10 dan kemokin CCL22, suatu kemokin yang berperan dalam perekrutan CCR4 Treg (Baeke et al., 2010). 1,25-dihidroksi vitamin D [1,25(OH), D] juga meregulasi peningkatan reseptor ILT3 di sel dendritik, yang berasosiasi dengan toleransi terhadap induksi dan modulasi dari produksi chemokine. Kombinasi dari efek sel $\mathrm{T}$ tersebut menyebabkan supresi pada sel T (Dusso et al,
2005). Dengan menekan maturasi sel dendritik dan meningkatkan ekspresinya pada sitokin khusus seperti IL-10, 1,25(OH) 2 D dapat meningkatkan tolerogenesis melalui supresi pada perkembangan sel Th1 dan menginduksi perkembangan Treg (Ghoreishi et al., 2009).

Ekspresi VDR pada sel imun dikontrol oleh sinyal sistem imun. sel $\mathrm{T}$ naive sangat rendah tingkat VDR-nya, reseptor ini berlimpah setelah sel T teraktivasi. Sebaliknya, diferensiasi monosit, baik menjadi makrofag atau sel dendritik disertai dengan penurunan ekspresi VDR, sehingga membuat sel dendritik kurang sensitif terhadap $1,25(\mathrm{OH}) 2 \mathrm{D} 3$. Selain itu, aktivasi jalur sinyal VDR juga menghambat pematangan sel dendritik, sebagaimana dibuktikan oleh adanya penurunan ekpresi MHC kelas II, molekul kostimulator (CD40, CD80, CD86 dan), dan menghambat 


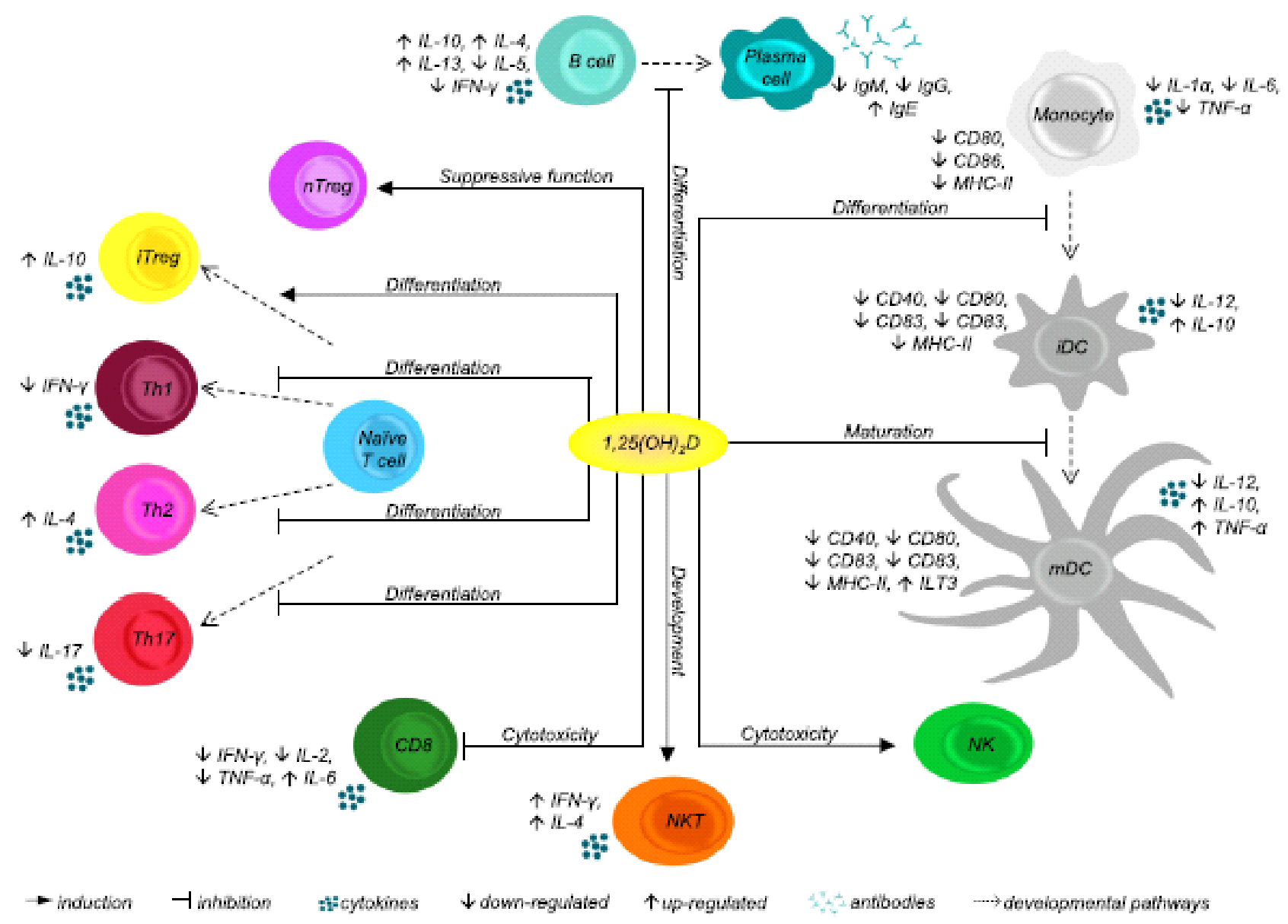

Gambar 4 Mekanisme Keterlibatan Vitamin D dalam Memodulasi Respon Imun.

Sel dendritik merupakan target utama untuk aktivitas imunomodulator vitamin D, Secara bersama menghambat diferensiasi prekursor monosit menjadi sel dendritik imatur dan menghambat maturasi sel dendritik. Vitamin D menekan sitokin sel Th1 dan sel Th17, meng-induksi sel Treg, menginduksi produksi IL-4 (sel Th2) dan meningkatkan fungsi sel NKT. Diferensiasi dan maturasi sel B juga terhambat. Th adalah sel T helper CD4 dengan subsetnya (Th1, Th2, Th3, Treg, Th17) yang berasal dari sel T naive (TH0). Semua sel T yang telah diuji mengekspresikan VDR, termaksud sel B dan sel NKT. Tanda panah induction menunjukkan aktivitas sitokin ditingkatkan oleh vitamin D. Sebaliknya, tanda inhibition menunjukkan aktivitas sitokin dihambat oleh vitamin D (Pellen et al., 2011).

maturasi sel dendritik penanda permukaan CD83. Menariknya, 1,25(OH)2D3 memainkan peran penting sel dendritik dalam mengikat dan menangkap antigen asing yang menginisiasi respon imun, karena hormon ini diregulasi oleh ekspresi reseptor manosa, molekul terlibat dalam serapan antigen, dan ini berkorelasi dengan peningkatan kapasitas endocytotic sel dendritik imatur (iDC) (Baeke et al., 2010).

Sel dendritik merupakan APC yang profesional yang mengawali respon imun innate dan respon imun adaptive, khususnya mempunyai peranan penting dalam meregulasi aktivasi, proliferasi, dan fungsi sel T (Ding et al., 2006). Sel dendritik memiliki tugas untuk menelan antigen dan mempresentasikan kembali antigen yang telah disederhanakan ke permukaan sel. Presentasi antigen yang telah sederhana pada permukaan sel dendritik sangat penting makna- nya, kerena dengan itu sel-sel limfosit bisa mengenal dan selanjutnya reaksi sistem imun secara bertahap akan dilaksanakan (Maddur et al., 2010).

Induksi imunitas adaptive dimulai ketika patogen dicerna oleh sel dendritik imatur (iDC) pada jaringan yang terinfeksi. Sel dendritik berasal dari prekursor dalam sumsum tulang bermigrasi menuju jaringan periperal tempat berhentinya, pada tempat ini sel dendritik berperan untuk menjaga lingkungannya dari serangan patogen. Sel dendritik yang telah memperoleh antigen akan segera memasuki pembuluh limfa dan masuk lymph node. Pada lymph node sel dendritik akan mengenalkan antigen yang dibawa kepada sel T naive (Abbas and Lichtman, 2006) (gambar 5). Sel dendritik matur (mDC) memiliki kemampuan dalam mengaktivasi sel $\mathrm{T}$ naïve dan menginisiasi respons sel $\mathrm{T}$. 


\section{KESIMPULAN}

Dari hasil pembahasan pada makalah dapat disimpulkan :

1. Vitamin D memiliki efek menghambat diferensiasi sel monosit menjadi sel dendritik dan menghambat proses maturasi sel den-dritik, kemudian mempertahankan sel dendritik dalam kondisi imatur.

2. Vitamin D menghambat aktivasi sel $\mathrm{T}$ yang tergantung sel dendritik, menurunkan sekresi sitokin Th1 dan Th2 serta menginduksi perkembangan sel $\mathrm{T}$ regulator.

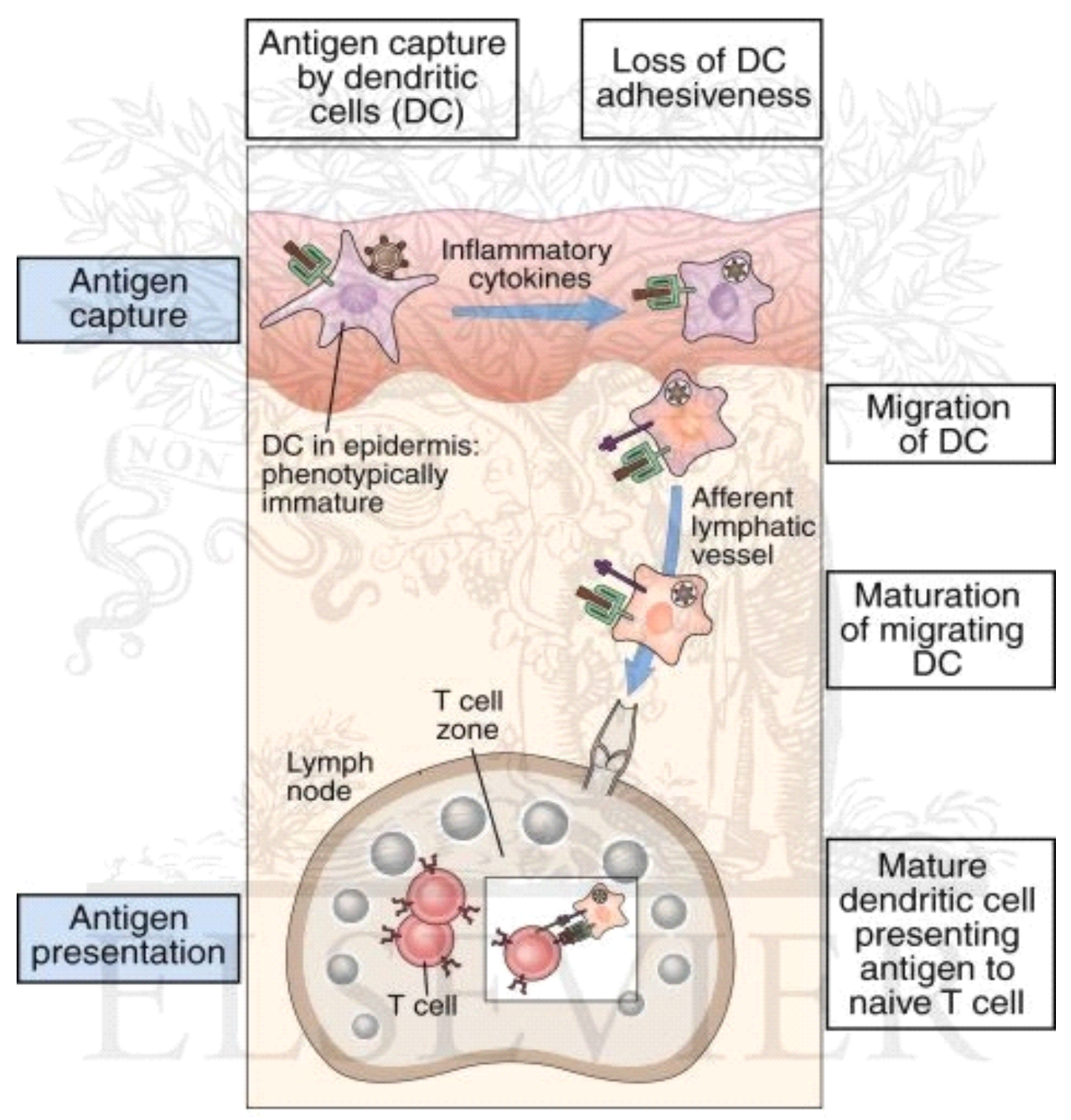

Gambar 5 : Sel Dendritik Menginisiasi Imunitas Adaptive.

Sel dendritik immature yang terletak pada daerah infeksi akan menangkap patogen dengan reseptor yang memediasi fagositosis, sedangkan antigennya akan ditangkap dengan mikrospinositosis. Sel dendritik ini terstimuli dan bermigrasi ke lymph node (LN) terdekat melalalui pembuluh limfatik. Pada LN sel dendritik telah masak sempurna (sel dendritik mature) dan kehilangan kemampuan sebagai sel fagosit. Pada LN, sel dendritik bertemu dan mengaktifkan sel T yang masuk LN melalui pembuluh darah khusus yang disebut high endothelial venule (HEV) (Abbas and Lichtman, 2006). 


\section{DAFTAR PUSTAKA}

Abbas, A., and A.H. Lichtman . 2006. Basic Immunology: Functions and Disorders of the Immune System, Updated Edition 20062007, 2nd ed. Philadelphia, Elsevier.

Adams, J.S., and M. Hewison. 2008. Unexpected actions of vitamin D: new perspectives on the regulation of innate and adaptive immunity. Nat. Clin. Pract. Endocrinol. Metab. 4(2): 80-90.

Adorini, L., and G. Penna. 2009. Dendritic cell tolerogenicity: a key mechanism in immunomodulation by vitamin d receptor agonist. Human Immunol. 70(5): 345-52.

Baeke, F., Takiishi, T., Hannelie, K., Conny, G., Chantal, M. 2010. Vitamin D: modulator of the immune system. Cuurent Opinion in Pharmacology. 10:482-496.

Bikle, D. 2009. Nonclassic actions of vitamin D. J. Clin. Endocrinol. Metab. 94(1): 26-34.

Chen, S., Sims, G.P., Chen, X.X., Gu, Y.Y., Chen, S., Lipsky, P.E. 2007. Modulatory effects of 1,25-dihydroxyvitamin D 3 on human B cell differentiation. J. Immunol. 17: 1634-1647.

Costenbader, K.H., Feskanich, D., Garcia, E.B., Holmes, M., Karison, E.W. 2008. Vitamin $\mathrm{D}$ intake and risk of systemic lupus erythematosus and rheumatoid arthritis in women. Ann. Rheum. Dis. 67(4): 530-535.

Cutolo, M. 2009. Vitamin D and autoimmune rheumatic diseases. Rheumatology. 48: 210212.

Ding, D., Mehta, H., McCune, J., Kaplan, M.J. 2006. Aberrant phenotype and function of myeloid dendritic cells in systemic lupus erythematosus. J. Immunol. 177: 5878-5889.

Dusso, A.D., Brown, A.J., Slatopolsky, E. 2005. Vitamin D. Am. J. Physiol. Renal. Physiol. 289: 828.

Ferreira, G.B., Manthieu, C., Overbergh, L. 2010. Understanding dendritic cell biology and its role in immunological disorders through proteomic profiling. Proteomics Clin. Appl. 4: 190-203.

Ghoreishi, M., Bach, P., Obst, J., Komba, M., Fleet, J.C., Dutz, J.P. 2009. Expansion of antigenspecific regulatory $\mathrm{T}$ Cells with the topical vitamin D analog calcipotriol. J. Immunol. 182: 6071-6078.

Holick, M.F. 2006. High prevalence of vitamin D inadequacy and implications for health. Mayo. Clin. Proc. 81(3): 353-373.

Kuwano, Y., Prazma, C.M., Yazawa, N., Watanabe, R., Ishiura, N., Kumanogoh, A., Okochi, H.,
Tamaki, K., Fujimoto, M., Tedder, T.F. 2007. CD83 influences cell-surface MHC class II expression on $\mathrm{B}$ cells and other antigenpreenting cells. International Immunology. 19(8): 977-992.

Maddur, M.S., Vani, J., Dimitrov, J.D., Balaji, K.N., Desmazes, S.L., Kaveri, S.V., Bayry, J. 2010. Dendritic cells in autoimmune diseases. The Open Arthritis Journal. 3: 1-7.

Nie, Y.Z., Mok, M.Y., Chan, G.C.F., Chan, A.W., Jin, O., Kavokondala, S., Lie, A.K.W., Lau, C.S. 2010. Phenotypic and functional abnormalities of bone marrow-derived dendritic cells in systemic lupus erythematosus. Arthtritis Research $\mathcal{E}$ Therapy. 12: 1-12.

Ou Jin, Sushma, K., Lingyun, S., Rong Fu, MoYin Mok, Albert, C., Joseph, Y., Chak, S.L. 2008. Systemic lupus erythematosus patients have increased number of circulating plasmacytoid dendritic cells, but decreased myeloid dendritic cells with deficient CD83 expression. LUPUS. 17: 654-662.

Rossi, M., and W.Y. James. 2005. Human dendritic cells: potent antigen-presenting cells at the crossroads to innate and adaptive immunity. J. Immunol. 175: 1373-1381.

Toubi, E., and Y. Shoenfeld. 2010. The role of vitamin $\mathrm{D}$ in regulating immune responses. IMAJ. 12: 174-175.

Vanamerongen, B.M., Dijkstra, C.D., Lips, P., Polman, C.H. 2004. Multiple sclerosis and vitamin D: an update. European Journal of Clinical Nutrition. 58: 1095-1109.

Vlad, G., Cortesini, R., Foca, N.S. 2005. License to heal: bidirectionalninteraction of antigen-spesific regulatory Tcells and tolerogenic APC. J. Immunol. 174: 59075914.

Zvi, I.B., aranow, C., Mackay, M., Stanevsky, A., Kamen, D.L., Marinescu, L.M., Collins, C.E., Gilkeson, G.S., Diamond, B., Hardin, J.A. 2009. The impact of vitamin D on dendritic cell fungtion in patiens with systemic lupus erythematosus. Plos One. 5(2): 1-8. 
